\title{
Effect of Tillage, Nutrition Sources and Weed Management on Growth and Productivity of Chickpea (Cicer arietinum L.)
}

\author{
K.C. Gupta*, Phool Chand and Vipin Kumar
}

Rajasthan Agricultural Research Institute, Durgapura, Jaipur, Rajasthan, India

*Corresponding author

\section{A B S T R A C T}

\section{Keywords \\ Tillage, Nutrition sources, Weed management, Growth, Yield attributes \\ Article Info \\ Accepted: \\ 07 October 2018 \\ Available Online: \\ 10 November 2018}

A field experiments was conducted during two consecutive rabi seasons of 2013-14 and 2014-15 to study the effect of tillage, nutrition sources and weed management practice on growth, yield attributes and yield of chickpea. The results revealed that The mean increases in primary branches, secondary branches, plant height, pods/ plant, seeds/ pod, seed index, seed yield and net returns under CT were over RT due to conventional tillage were $7.84,9.44,7.52,29.37,4.72$ and 4.43 per cent and $286.6 \mathrm{~kg} / \mathrm{ha}$ and Rs. 8258/ha, respectively over reduced tillage. Similarly, the mean increases in seed yield due to INM was 8.53 per cent over recommended doses of fertilizer through chemical fertilization. Further, the mean increases in no. of pods/plant and seed yield under hand weeding was 6.92 and 20.32 percent, respectively over chemical weeding.

\section{Introduction}

In Rajasthan, chickpea is normally grown as a second crop after short duration kharif crops like pearmillet or moongbean under rainfed conditions or on conserved soil moisture. It is grown on about $1.55 \mathrm{M}$ ha area, producing about $1.41 \mathrm{M}$ tones with an average productivity of $911 \mathrm{~kg} / \mathrm{ha}$ (Anon (2016-17). Soil tillage affects the important properties of soil such as temperature, moisture, and soil density. For optimum plant growth and the yield, the establishment of optimum plant population through the proper tillage system may be the suitable strategy without deteriorating soil health. Due to poor physical properties and microbial activity in soil, integrated nutrient management may be suitable strategies to sustain soil health with improvement in crop productivity. Presence of weeds severely affects crop productivity and quality of crops by competing with the crops for space, moisture and nutrients. Keeping in view, the present study was undertaken to evaluate the effect of different tillage practices, sources of nutrients and weed management on growth, yield along with their economics.

\section{Materials and Methods}

The field experiment was carried out at research farm of Rajasthan Agricultural Research Institute, Durgapura, Jaipur (Raj.) during two consecutive rabi seasons of 201314 and 2014-15. Durgapura, Jaipur is located 
at $26^{\circ} 51^{\prime} \mathrm{N}$ latitude and $75^{\circ} 47^{\prime} \mathrm{E}$ longitude at an elevation of $390 \mathrm{M}$ above mean sea level. The soil type of the experimental site was sandy loam with sand $(86.8 \%)$, silt $(5.6 \%)$, clay $(7.6 \%), \mathrm{pH} 7.8,0.17 \%$ organic carbon and $139.2,36.6$ and $238.0 \mathrm{~kg} / \mathrm{ha}$ available $\mathrm{N}$, $\mathrm{P}_{2} \mathrm{O}_{5}$ and $\mathrm{K}_{2} \mathrm{O}$, respectively. The present experiment consist of 08 treatments combinations two each of tillage practices(i.e. conventional tillage and reduced tillage), nutrition Sources (Recommended doses of fertilizer and INM) and weed management (Chemical i.e. pre-emergence application of pendimethalin@0.75 kg a.i /ha, Two HW at 25-30 and 40-45 DAS)were evaluated in Randomized Block Design with three replications. The crop was sown on 05.11.2013 and 09.11.2014 at a crop geometry of $30 \times 10 \mathrm{~cm}$. Net monetary returns and B: C ratio for each treatment was also calculated.

\section{Results and Discussion}

\section{Effect of tillage}

Data (Table 1 and 2) revealed that significantly higher number of primary branches, secondary branches /plant, plant height, number of pods /plant, number of seeds /pod and test weight was recorded under conventional tillage (CT) compared to reduced tillage (RT) during both years of experimentation. The mean increases in primary branches, secondary branches, plant height, pods/ plant, seeds/ pod and seed index due to conventional tillage were $7.84,9.44$, $7.52,29.37,4.72$ and 4.43 per cent, respectively over reduced tillage. The better growth and yield attributes under conventional tillage could be ascribed to better seed bed preparation under conventional tillage facilitates better root growth which favour better absorption of nutrients and moisture from different soil layers.

Further, the data (Table 3) indicated that significantly higher seed yield of 1232 and
$1325.3 \mathrm{~kg} / \mathrm{ha}$ was obtained under conventional tillage compared to reduced tillage. Similarly the higher net returns and $\mathrm{B}$ : $\mathrm{C}$ ratio was also obtained under conventional tillage. The mean increases in seed yield and net returns under CT were $286.6 \mathrm{~kg} / \mathrm{ha}$ and Rs.8258/ha over RT. The increases in seed yield could be attributed to better growth and yield attributes under CT. Similar findings were also reported by Chouhan et al., (2017).

\section{Effect of source of nutrition}

Data Table 1 and 2 indicates that the integrated nutrient management marginally improved growth and yield attributes of chickpea and did not attain statistical significance over chemical fertilization during both years of experimentation. However, significantly higher seed yield of $1277.1 \mathrm{~kg} / \mathrm{ha}$ was recorded under INM during 2014-15 and statistical at par yield was recorded during 2013-14.

The mean increases in seed yield due to INM was 8.53 per cent over recommended doses of fertilizer through chemical fertilization. Similarly higher mean net returns (Rs.15560/ha) and mean B: C ratio (1.66) was also obtained under INM. Similar findings were also reported by Rana et al., (2007) and Sohu et al., (2015).

\section{Effect of weed control practices}

The results revealed that twice hand weeding marginally improved growth characters (primary and secondary branches /plant and plant height) and yield attributing characters (seeds/pod and seed index) compared to recommended herbicide. However, the no of pods /plant were significantly improved under twice hand weeding during both the years. The mean increases in no. of pods/plant underhand weeding was 6.92 per cent over recommended herbicide. 
Table.1 Response of chickpea to tillage, nutrition source and weed control measures

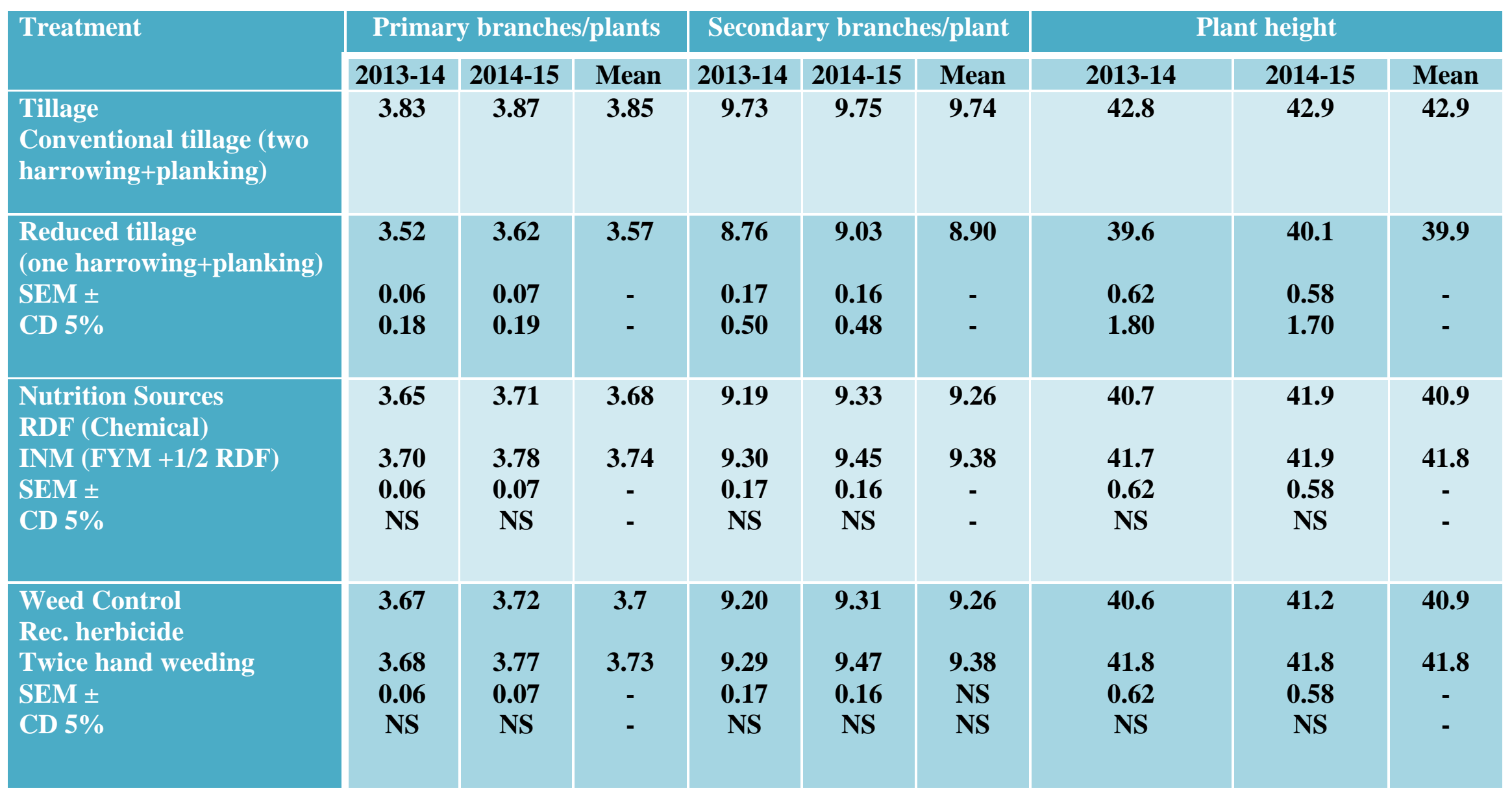


Table.2 Response of chickpea to tillage, nutrition source and weed control measures on growth yield attributes

\begin{tabular}{|c|c|c|c|c|c|c|c|c|c|}
\hline \multirow[t]{2}{*}{ Treatment } & \multicolumn{3}{|c|}{ No. of Pods/plant } & \multicolumn{3}{|c|}{ No. of seed/pod } & \multicolumn{3}{|c|}{100 seed weight } \\
\hline & 2013-14 & 2014-15 & Mean & 2013-14 & 2014-15 & Mean & 2013-14 & 2014-15 & Mean \\
\hline Conventional & 18.2 & 18.8 & 18.5 & 1.32 & 1.34 & 1.33 & 19.02 & 19.16 & 19.09 \\
\hline Reduced & 13.8 & 14.8 & 14.3 & 1.26 & 1.27 & 1.27 & 18.18 & 18.38 & 18.28 \\
\hline SEM \pm & 0.29 & 0.31 & - & 0.02 & 0.02 & - & 0.22 & 0.21 & - \\
\hline CD 5\% & 0.90 & 0.90 & - & 0.06 & 0.06 & - & 0.64 & 0.60 & - \\
\hline $\begin{array}{l}\text { Nutrition Sources } \\
\text { RDF }\end{array}$ & 15.8 & 16.4 & 16.1 & 1.29 & 1.30 & 1.30 & 18.56 & 18.76 & 18.66 \\
\hline INM & 16.2 & 17.2 & 16.7 & 1.29 & 1.31 & 1.30 & 18.64 & 18.78 & 18.71 \\
\hline SEM \pm & 0.29 & 0.31 & - & 0.02 & 0.02 & - & 0.22 & 0.21 & - \\
\hline CD 5\% & NS & NS & - & NS & NS & - & NS & NS & - \\
\hline $\begin{array}{l}\text { Weed Control } \\
\text { Rec. herbicide }\end{array}$ & 15.4 & 16.3 & 15.9 & 1.28 & 1.30 & 1.29 & 18.59 & 18.76 & 18.68 \\
\hline Twice hand weeding & 16.6 & 17.3 & 17.0 & 1.30 & 1.31 & 1.31 & 18.61 & 18.78 & 18.70 \\
\hline $\mathrm{SEM} \pm$ & 0.29 & 0.31 & - & 0.02 & 0.02 & - & 0.22 & 0.21 & - \\
\hline CD $5 \%$ & 0.90 & 0.90 & - & NS & NS & - & NS & NS & - \\
\hline
\end{tabular}

Table.3 Effect of tillage, nutrient level and weed control measures on seed yield and economics of chickpea

\begin{tabular}{|c|c|c|c|c|c|c|}
\hline \multirow[t]{2}{*}{ Treatments } & \multicolumn{3}{|c|}{ Seed yield (kg/ha) } & \multirow{2}{*}{$\begin{array}{l}\text { Mean Gross } \\
\text { Return (Rs/ha) }\end{array}$} & \multirow{2}{*}{$\begin{array}{l}\text { Mean Net } \\
\text { returns Rs/ha }\end{array}$} & \multirow{2}{*}{$\begin{array}{l}\text { Mean B: C } \\
\text { ratio }\end{array}$} \\
\hline & 2013-14 & 2014-15 & Mean & & & \\
\hline \multicolumn{7}{|l|}{ Tillage } \\
\hline Conventional Tillage (Two harrowing + planking) & 1232 & 1325.3 & 1278.7 & 42197 & 20232 & 1.92 \\
\hline Reduced Tillage (one harrowing + planking) & 877 & 1107.2 & 992.1 & 32739 & 11974 & 1.58 \\
\hline $\mathrm{CD}(\mathrm{P}=\mathbf{0 . 0 5})$ & 91.6 & 60.3 & - & - & - & - \\
\hline \multicolumn{7}{|l|}{ Nutrient levels } \\
\hline RDF & 1022 & 1155.4 & 1088.7 & 35927 & 13962 & 1.64 \\
\hline INM(FYM+1/2 RDF) & 1086 & 1277.1 & 1181.6 & 38993 & 15560 & 1.66 \\
\hline $\mathrm{CD}(\mathrm{P}=\mathbf{0 . 0 5})$ & NS & 60.3 & - & - & - & - \\
\hline \multicolumn{7}{|l|}{ Weed Control } \\
\hline Recom. Herbicide (pendi @ 0.75 kg a.i/ha) & 903 & 1158.4 & 1030.7 & 34013 & 14398 & 1.73 \\
\hline Manual weeding Twice & 1206 & 1274.2 & 1240.1 & 40923 & 14958 & 1.58 \\
\hline $\mathrm{CD}(\mathrm{P}=\mathbf{0 . 0 5})$ & 91.6 & 60.3 & - & - & - & - \\
\hline
\end{tabular}


Further, the data (Table 3) indicates that that significantly higher seed yield of chickpea (1206 and $1274.2 \mathrm{~kg} / \mathrm{ha}$ ) was recorded under two hand weeding during 2013-14 and 201415 compared to chemical weeding. The mean increases in seed yield due to manual weeding was 20.32 percent over chemical weeding. The improvement in seed yield under manual weeding could be ascribed to better aeration which may lead to favourable impact on plant growth and root development which results in better uptake of moisture and nutrient from deeper soil layers. Similar findings were also reported by Chavada et al., (2017).

\section{References}

Anonymous. 2016-17. Rajasthan Agricultural Statistics at a glance, 2016-17. Commissioner ate of Agriculture, Rajasthan, Jaipur pp: 84.

Chauhan, A., Jha, G., Chourasiya, A., Jha, A., and Joshi, J. K. 2017. Effect of tillage and weed management practices and growth productivity and energy analysis of late- sown chickpea. International Journal of Agriculture Sciences. 9(5): 3779-3781

Chavada, J.N., Patel, C.K., Patel, S.B., Panchal, P.P. and Patel, G.N. 2017. Weed management in chickpea (Cicer arietinum L.) under north Gujarat conditions. International Journal of Science, Environment and Technology. 6(3): $2018-2025$.

Sohu, I., Gandahi, A. W., Bhutto, G. R., Sarki, M. S. and Gandahi, R. 2015. Growth and Yield Maximization of Chickpea (Cicer arietinum) Through Integrated Nutrient Management Applied to Rice-Chickpea Cropping System. Sarhad Journal of Agriculture. 31(2): 131-138

Vivek. Rana, N. S., Dhyani, B. P., Singh, R. and Yadav, R. P. 2015. Integrated nutrient Management in Chickpea (Cicer arietinum). Journal of Farming Systems Research \& Development. 13 (2): 288-289

\section{How to cite this article:}

Gupta, K.C., Phool Chand and Vipin Kumar. 2018. Effect of Tillage, Nutrition Sources and Weed Management on Growth and Productivity of Chickpea (Cicer arietinum L.). Int.J.Curr.Microbiol.App.Sci. 7(11): 706-710. doi: https://doi.org/10.20546/ijcmas.2018.711.084 